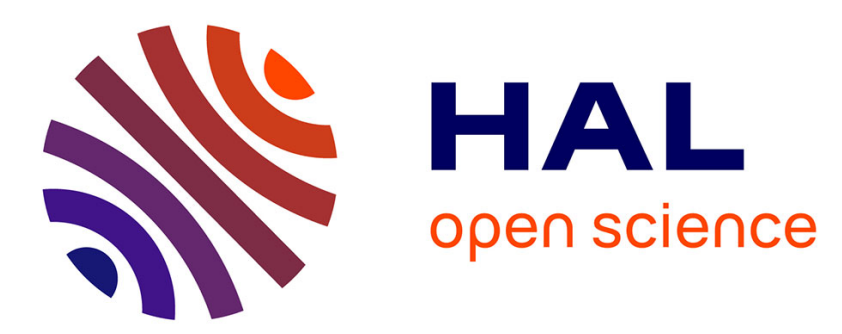

\title{
The changes of age-related molecules in the trophocytes and fat cells of queen honeybees (Apis mellifera)
}

\author{
Yu-Shan Hsieh, Chin-Yuan Hsu
}

\section{To cite this version:}

Yu-Shan Hsieh, Chin-Yuan Hsu. The changes of age-related molecules in the trophocytes and fat cells of queen honeybees (Apis mellifera). Apidologie, 2011, 42 (6), pp.728-739. 10.1007/s13592-011-0085x . hal-01003623

\section{HAL Id: hal-01003623 \\ https://hal.science/hal-01003623}

Submitted on 1 Jan 2011

HAL is a multi-disciplinary open access archive for the deposit and dissemination of scientific research documents, whether they are published or not. The documents may come from teaching and research institutions in France or abroad, or from public or private research centers.
L'archive ouverte pluridisciplinaire HAL, est destinée au dépôt et à la diffusion de documents scientifiques de niveau recherche, publiés ou non, émanant des établissements d'enseignement et de recherche français ou étrangers, des laboratoires publics ou privés. 


\title{
The changes of age-related molecules in the trophocytes and fat cells of queen honeybees (Apis mellifera)
}

\author{
Yu-Shan $\mathrm{HsieH}^{2}$, Chin-Yuan Hsu ${ }^{1,2}$ \\ ${ }^{1}$ Department of Biomedical Sciences, Chang Gung University, 259, Wen-Hwa 1st Road, Kwei-Shan, Tao-Yuan 333, \\ Taiwan \\ ${ }^{2}$ Graduate Institute of Basic Medical Science, Chang Gung University, Tao-Yuan, Taiwan
}

Received 21 December 2010 - Revised 2 March 2011 - Accepted 28 March 2011

\begin{abstract}
Queen honeybees (Apis mellifera) have much longer lifespans than worker bees. Although the expression of age-related molecules in the trophocytes and fat cells of young and old workers have been determined, the expression of age-related molecules in queens is unknown. In this study, we examined the expression of age-related molecules in the trophocytes and fat cells of young and old queens. Molecular analyses detected no differences in telomerase activity or telomere lengths between trophocytes and fat cells from young and old queens, indicating that these cells do not divide in adulthood. Further assays showed that old queens has higher non-homogeneous cellular morphology, senescence-associated $\beta$-galactosidase (SA- $\beta$-Gal) activity, accumulation of lipofuscin granules, lipid peroxidation, and protein oxidation compared to young queens. These results demonstrate that age-related molecules can be used to evaluate aging in the trophocytes and fat cells of queens and to lay the foundation for further study of the mechanisms that delay cellular aging in the trophocytes and fat cells of queens.
\end{abstract}

aging / trophocyte / fat cell / queen / honeybee

\section{INTRODUCTION}

Cellular senescence is a complicated process of progressive deterioration. Aging leads to a gradual diminishing of biological functions and increased incidences of age-associated diseases. Understanding the biology of aging will not only clarify the mechanisms involved in lifespan extension, but can also lead to the improved health of organisms.

Age-related molecules have been used as indices of aging in many organisms (Tian et al. 1998; Kishi et al. 2003; Genade et al. 2005; Zheng et al. 2005; Hsu et al. 2008; Hsu and Chiu 2009). These age-related molecules include SA- $\beta$-Gal (Dimri et al. 1995), lipofuscin granules

Corresponding author: C-Y. Hsu, hsu@mail.cgu.edu.tw Manuscript editor: David Tarpy
(Nakano et al. 1995), lipid peroxidation (Draper and Hadley 1990; Inal et al. 2001; Almeida et al. 1998), protein oxidation (Oliver et al. 1987; Welis-Knecht et al. 1993), telomerase activity (Davis et al. 2005; Argyle et al. 2003), and telomere length (Davis et al. 2005; Hastings et al. 2004; Argyle et al. 2003). Numerous studies have shown that the expression of age-related molecules in cells and tissues increases or decreases with advancing age. Accordingly, the fluctuation of age-related molecules has been used to evaluate the degree of aging in organisms (Mecocci et al. 1999; Hsu et al. 2008; Hsu and Chiu 2009; Hsieh and Hsu 2011).

Honeybees (Apis mellifera) are an excellent model system for studying aging because they live in large colonies, they are easily manipulated, and their genome has been sequenced. Therefore, honeybees have been evaluated in 
many studies on aging (Remolina et al. 2007; Corona et al. 2007; Amdam and Page 2005; Amdam et al. 2004; Tofilski 2000; Robertson and Gordon 2006; Jemielity and Keller 2007; Rueppell et al. 2007a). A variety of honeybee specimens, including spermathecae, muscle, ventriculi, hemolymph plasma, semen, brain, trophocytes, and fat cells, have been used to study oxidative stress (Weirich et al. 2002; Seehuus et al. 2006a, b; Williams et al. 2008; Collins et al. 2004) and aging (Hsieh and Hsu 2011).

Especially, workers and queens develop from the same genome, but workers have a short lifespan (15-38 days in the summer and 150200 days in the winter) while queens have a long lifespan (1-2 years, with a maximum of up to 8 years) (Page and Peng 2001; Omholt and Amdam 2004; Rueppell et al. 2007b; Remolina and Hughes 2008). This provides a unique resource for studying the causes of longevity. Comparing workers and queens, the following differences have been established:

(1) queens eat royal jelly, whereas workers eat glandular secretions, honey, and pollen (Winston 1987).

(2) queens live in the hive except during mating flights and colony fission. They generally lay 1,500-2,000 eggs per day throughout their lives (Camazine 1991). In contrast, workers spend only the first 2 weeks of life in the hive. Workers perform tasks such as comb-building, cellcleaning, and brood-nursing before transitioning to the foraging stage. In the foraging stage, workers fly up to $21 \mathrm{~km}$ per day to collect nectar and pollen for the hive (Neukirch 1982).

We recently assayed the expression of agerelated molecules in the trophocytes and fat cells of young and old workers (Hsieh and Hsu 2011). Trophocytes, which are large and irregularly shaped, and fat cells, which are small and spherical, attach to one another to form a single layer of cells around each segment of the honeybee abdomen. Trophocytes and fat cells are immersed in body fluid, and have the potential to be used to test anti-aging drugs when drugs are microinjected into the body fluid (Hsieh and Hsu 2011). Therefore, trophocytes and fat cells are good target cells for cellular senescence studies. The assay of agerelated molecules in the trophocytes and fat cells of workers showed that old workers exhibited more non-homogeneous cellular morphology, SA- $\beta$-Gal, lipofuscin granules, lipid peroxidation, and protein oxidation than newly emerged workers (Hsieh and Hsu 2011). In this study, we examined the expression of agerelated molecules in the trophocytes and fat cells of young and old queens.

\section{MATERIALS AND METHODS}

\subsection{Queen honeybees}

Queen honeybees (Apis mellifera) were purchased from a single commercial breeder (Hsinchu, Taiwan) from different hives, and collected on the same dates for the same experiments in May. The age of young queens was approximately 2 months old. The age of old queens was about 16 months old.

\subsection{Light microscopy (LM)}

Trophocytes and fat cells were freshly isolated from a young and an old queen, fixed in 4\% formaldehyde at room temperature, mounted onto glass slides, and viewed under LM (Olympus BX-61, Tokyo, Japan). This experiment was repeated three times.

\subsection{Transmission electron microscopy (TEM)}

Trophocytes from a young and an old queen were fixed in $2.5 \%$ glutaraldehyde in a $0.1 \mathrm{M}$ phosphate buffer containing $0.35 \mathrm{M}$ sucrose at $\mathrm{pH}$ 7.4 for $30 \mathrm{~min}$ at $25^{\circ} \mathrm{C}$, and postfixed in $1 \%$ osmium tetroxide in a $0.1 \mathrm{M}$ phosphate buffer with $0.35 \mathrm{M}$ sucrose at $\mathrm{pH} 7.4$ for $2 \mathrm{~h}$. Trophocytes were dehydrated via an ethanol series and embedded in Spurr's resin. Thin sections $(60-90 \mathrm{~nm}$ thick) were cut with a diamond knife, stained with uranyl 
acetate and lead citrate, and then examined using a TEM (JEOL JEM-2000EXII, Tokyo, Japan), operating at an accelerated voltage of $100 \mathrm{kV}$ (Hsu and $\mathrm{Li}$ 1993; Hsu 2004). This experiment was repeated three times.

\subsection{Telomerase activity assay}

Telomerase activity was measured using the telomere repeat amplification protocol (TRAP) by using the TRAPeze XL Telomerase Detection Kit (Chemicon, Temecula, CA, USA; S7707). Briefly, $0.2 \mathrm{~g}$ of trophocytes and fat cells was isolated from three young and old queens, treated with $1.5 \mathrm{ml}$ icecold lysis buffer ( $0.5 \%$ 3-([3-cholamidopropyl]-dimethylammonio)-1-propane sulfonate (CHAPS), $10 \mathrm{mM}$ Tris-HCl, $\mathrm{pH} 7.5,1 \mathrm{mM} \mathrm{MgCl} 2,1 \mathrm{mM}$ EGTA, $10 \%$ glycerol, $5 \mathrm{mM} \beta$-mercaptoethanol, and $1 \mathrm{mM}$ PMSF), then incubated on ice for $30 \mathrm{~min}$. After centrifugation at $15,000 \mathrm{~g}$ for $30 \mathrm{~min}$ at $4{ }^{\circ} \mathrm{C}$, DNA concentration in the supernatant was measured by UV absorbance before it was stored at $-80^{\circ} \mathrm{C}$. Telomerase extension products $(2 \mu \mathrm{g} / \mu \mathrm{l})$ were amplified by a three-step PCR $\left(94^{\circ} \mathrm{C}\right.$ for $30 \mathrm{~s}, 59^{\circ} \mathrm{C}$ for $30 \mathrm{~s}, 72^{\circ} \mathrm{C}$ for $\left.60 \mathrm{~s}\right)$ for $38 \mathrm{PCR}$ cycles with $\mathrm{TS}$ primer (5'-AATCCGTCGAGCAGAGTT-3') and CX primers (5'-CCCGGGCCTAACCTAACCTAA-3' for bees) for negative control, young queens, and old queens. Positive control (293 T cells) was mixed with TS primer and CX primers (5'-GCGCGGCTAACCC TAACCCTAACCCTACCC-3' for mammal). These products were resolved in $10 \%$ polyacrylamide (Kim and Wu 1997). Telomerase was quantified by normalizing the band intensities of the characteristic every 6-bp telomerase-specific ladder band by using Image J software (NIH, Bethesda, MA, USA). This experiment was repeated three times.

\subsection{Telomere length assay}

Telomere length analysis was performed by Southern blot hybridization using the Telo TAGGG Determination Kit (Roche, Mannheim, Germany; 12209136001). Briefly, high-molecular-weight genomic DNA was isolated from trophocytes and fat cells from three young and old queens by using the Easypure Genomic DNA Mini Kit (Bioman, Taipei, Taiwan; EP-2500), digested with proteinase
$\mathrm{K}$ and RNase in lysis buffer $(10 \mathrm{mM}$ Tris- $\mathrm{HCl}$, $100 \mathrm{mM} \mathrm{NaCl}, 100 \mathrm{mM}$ EDTA, 0.5\% SDS and $0.1 \mathrm{mg} / \mathrm{ml} \mathrm{RNase}$ ), extracted with isopropanolethanol, and verified by standard agarose gel electrophoresis. Next, $0.5 \mu \mathrm{g} / \mu \mathrm{l}$ of genomic DNA was digested with Hind III at $37^{\circ} \mathrm{C}$ for $3 \mathrm{~h}$ and subjected to $0.8 \%$ agarose gel electrophoresis for $4 \mathrm{~h}$ at $75 \mathrm{~V}$. Digested DNA was then transferred to Genescreen Plus Hybridization Transfer Membrane (PerkinElmer, CA, USA; NEF986001PK). A diglabeled oligonucleotide probe (5'-(GGATT) $)_{5}$-dig-3') was hybridized to the membrane, and detected using enhanced chemiluminescence (TeloTAGG Telomere Length Assay) (Okazaki et al. 1993). Telomere length was analyzed according to the manufacturer's protocol (Roche, Mannheim, Germany; 12209136001) with ImageQuant image analysis software (version 5.2, Molecular Dynamics, CA, USA). This experiment was repeated three times.

\subsection{SA- $\beta$-Gal expression assay}

SA- $\beta$-Gal expression was carried out as described previously (Dimri et al. 1995). Briefly, trophocytes and fat cells were isolated from a young and an old queen, fixed in $4 \%$ paraformaldehyde at room temperature, immersed in SA- $\beta$-Gal staining solution at $37^{\circ} \mathrm{C}$, washed with $\mathrm{PBS}$, mounted onto glass slides, and viewed under LM (Olympus BX-61, Tokyo, Japan). SA- $\beta$-Gal area was determined using QWin image processing and analysis software (version 2.5, Leica, Wetzlar, Germany). This experiment was repeated three times.

\subsection{Lipofuscin granules assay}

The level of lipofuscin was determined as previously described (Brunk and Terman 2002). Briefly, trophocytes and fat cells were isolated from a young and an old queen, mounted onto glass slides, and viewed under a confocal laser scanning microscope (Leica TCS SP2; Leica, Wetzlar, Germany) with blue (450-490 nm) excitation light and a 520-nm emission filter at room temperature. The area of lipofuscin expression was determined using QWin image processing and analysis software (version 2.5, Leica, Wetzlar, Germany). This experiment was repeated three times. 


\subsection{Lipid peroxidation assay}

Sample preparation was carried out as previously described (Hsieh and Hsu 2011). Briefly, trophocytes and fat cells from three young and old queens were freshly homogenized in $1.3 \mathrm{ml}$ of phosphate buffer containing protease inhibitors (leupeptin, pepstatin and phenylmethylsurfonyl fluoride) and centrifuged at $5000 \mathrm{~g}$ for $10 \mathrm{~min}$ at $4{ }^{\circ} \mathrm{C}$. The resulting supernatant was immediately used for the assays described below. Protein concentration was determined using the protein assay reagent (\#500-0006, Bio-Rad, Hercules, CA, USA). Lipid peroxidation assay was carried out as previously described (Hsieh and Hsu 2011). The fresh supernatant described above was mixed with trichloroacetic acid (TCA) and thiobarbituric acid (TBA). The absorbance of resulting mixture was then measured using a Thermo spectrophotometer at a wavelength of $532 \mathrm{~nm}$ at room temperature. Malondialdehyde (MDA) concentration was calculated by multiplying the absorbance by the MDA-TBA complex absorbance coefficient $\left(1.56 \times 10^{5} \mathrm{~cm}^{-1} \mathrm{M}^{-1}\right)$, and expressed as nanomoles per gram of protein. This experiment was repeated three times.

\subsection{Protein oxidation assay}

Protein oxidation assay was carried out as previously described (Hsieh and Hsu 2011). Briefly, the fresh supernatant described above was mixed with 2,4-dinitrophenylhydrazones (DNPH) in $2 \mathrm{M} \mathrm{HCl}$ or $2 \mathrm{M} \mathrm{HCl}$ alone (control), incubated for $1 \mathrm{~h}$ at room temperature, precipitated with TCA, and centrifuged at 7,800 $\mathrm{g}$ for $3 \mathrm{~min}$. The resulting pellet was washed with ethanol/ethyl acetate and dissolved in $6 \mathrm{M}$ guanidine ( $\mathrm{pH}$ 2.3). Protein oxidation, expressed as nanomoles of carbonyl groups per mg of protein, was calculated using the differential absorbance of experimental (DNPH in $\mathrm{HCl})$ and control $(\mathrm{HCl})$ samples at a wavelength of $370 \mathrm{~nm}$, and the extinction coefficient of aliphatic hydrazones $\left(22.0 \mathrm{mM}^{-1} \mathrm{~cm}^{-1}\right)$. This experiment was repeated three times.

\subsection{Statistical analysis}

Differences in mean values between the two age groups were examined using two-sample $t$-test. Differences in telomerase activity were determined by one-way ANOVA and Tukey's HSD for pairwise comparisons. A $p$-value of less than 0.05 was considered statistically significant. $N$ represents the number of independent experiments.

\section{RESULTS}

\subsection{Cellular morphology of trophocytes and fat cells in young and old queens}

The morphology of trophocytes and fat cells under LM showed a greater accumulation of brown material in old queens than in young queens (Figure 1a, b). Trophocytes were further examined under TEM, old queen trophocytes showed loose organelle morphology, dark organelle inclusion, a crowded distribution of
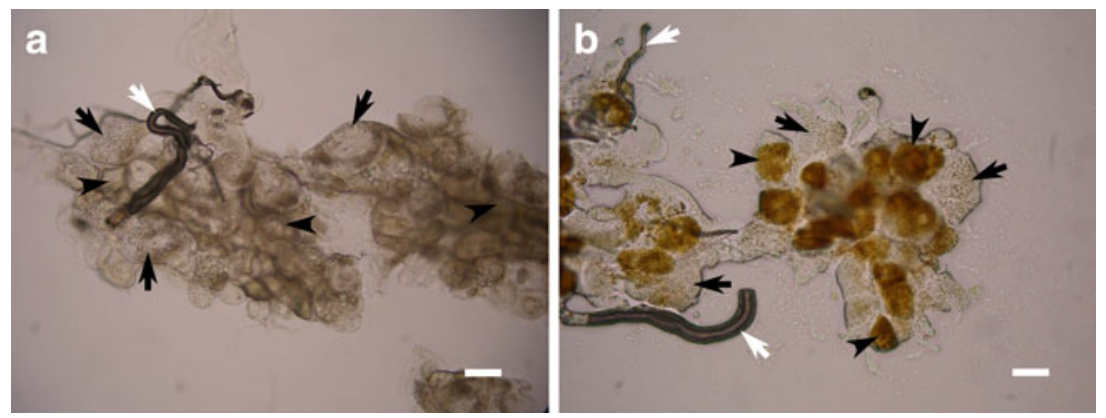

Figure 1. The LM images showing the morphology of the trophocytes and fat cells of a young queen (a) and an old queen (b). Black arrows point to trophocytes. White arrows point to trachea. Arrowheads point to fat cells. Scale bar, $50 \mu \mathrm{m}$. 
organelles, and oil accumulation compared to young queens (Figure 2a, b).

\subsection{Telomerase activity and telomere length do not change with age in trophocytes and fat cells}

To explore whether the trophocytes and fat cells of queens can divide, we assayed telomerase activity and telomere length in the trophocytes and fat cells of young and old queens. All queens showed a telomerase amplification pattern similar to the negative control, indicating a lack of telomerase activity in these cells (Figure 3a). Statistical analyses further confirmed these results $(P<0.01)$ (Figure $3 \mathrm{c})$. Telomere lengths were the same in young and old queens, suggesting that telomere length does not change with age. Telomere lengths ranged from $8.89 \pm 0.01 \mathrm{~kb}$ to $53.27 \pm 0.20 \mathrm{~kb}$ in young queens and $8.86 \pm 0.03 \mathrm{~kb}$ to $53.16 \pm 0.51 \mathrm{~kb}$ in old queens (Figure $3 \mathrm{~b}$ ). The average telomere length was $17.43 \pm 0.90 \mathrm{~kb}$ in young queens and $16.89 \pm 1.02 \mathrm{~kb}$ in old queens (Figure $3 \mathrm{~d}$ ). These results indicate that trophocytes and fat cells in queens do not divide during adulthood.

\subsection{SA- $\beta-$ Gal and lipofuscin granule accumulation increase with age in trophocytes and fat cells}

To evaluate the expression of age-related molecules in trophocytes and fat cells, we analyzed the expression levels of SA- $\beta-\mathrm{Gal}$ and lipofuscin in young and old queens. SA-
$\beta$-Gal activity was not detected in the trophocytes and fat cells of young queens; however, SA- $\beta$-Gal activity was clearly observed in cells of old queens (Figure 4a). Statistical analyses revealed that the area within trophocytes and fat cells that stained positive for SA- $\beta$-Gal activity increased with age $(P<0.05)$, indicating that SA- $\beta$-Gal expression in these cells is associated with aging (Figure 4b). Lipofuscin granules showed little to no accumulation in the trophocytes and fat cells of young queens, whereas lipofuscin granules accumulated to high levels in the cells of old queens (Figure 4c). Statistical analyses showed that the area within trophocytes and fat cells occupied by lipofuscin increased with age $(P<0.05)$, indicating that lipofuscin accumulation is associated with aging (Figure 4d).

\subsection{Lipid peroxidation, protein oxidation, and ROS levels increase with age in trophocytes and fat cells}

To further examine molecular damage in trophocytes and fat cells with age, we assayed lipid peroxidation and protein oxidation in young and old queens. Lipid peroxidation was assessed by determining the levels of MDA, a metabolite of lipid peroxidation. The mean MDA concentrations in trophocytes and fat cells were $0.13 \pm 0.01 \mathrm{nmol} / \mathrm{mg}$ protein in young queens and $0.27 \pm 0.01 \mathrm{nmol} / \mathrm{mg}$ protein in old queens $(P<0.05)$, suggesting that lipid peroxidation is associated with aging (Figure 5a). Protein oxidation was assessed by determining
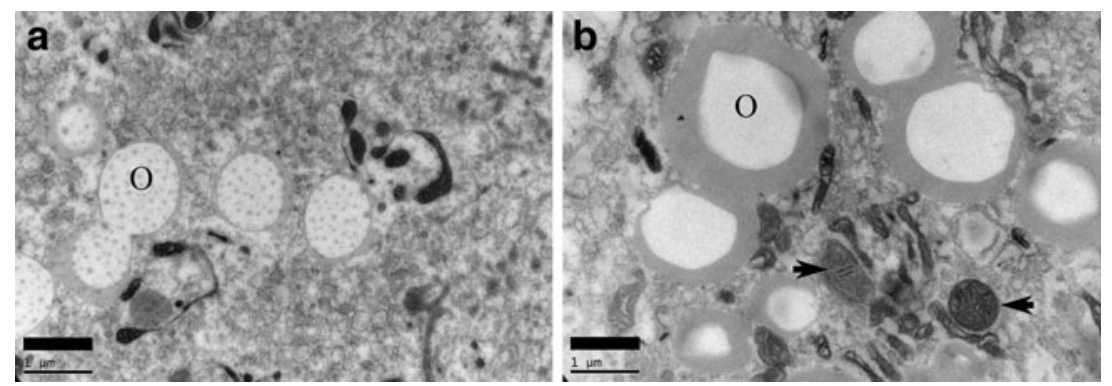

Figure 2. The TEM image showing the morphology of trophocytes in young queens (a) and old queens (b). $O$, oil body. Scale bar, $1 \mu \mathrm{m}$. Arrow in (b) shows mitochondria. 

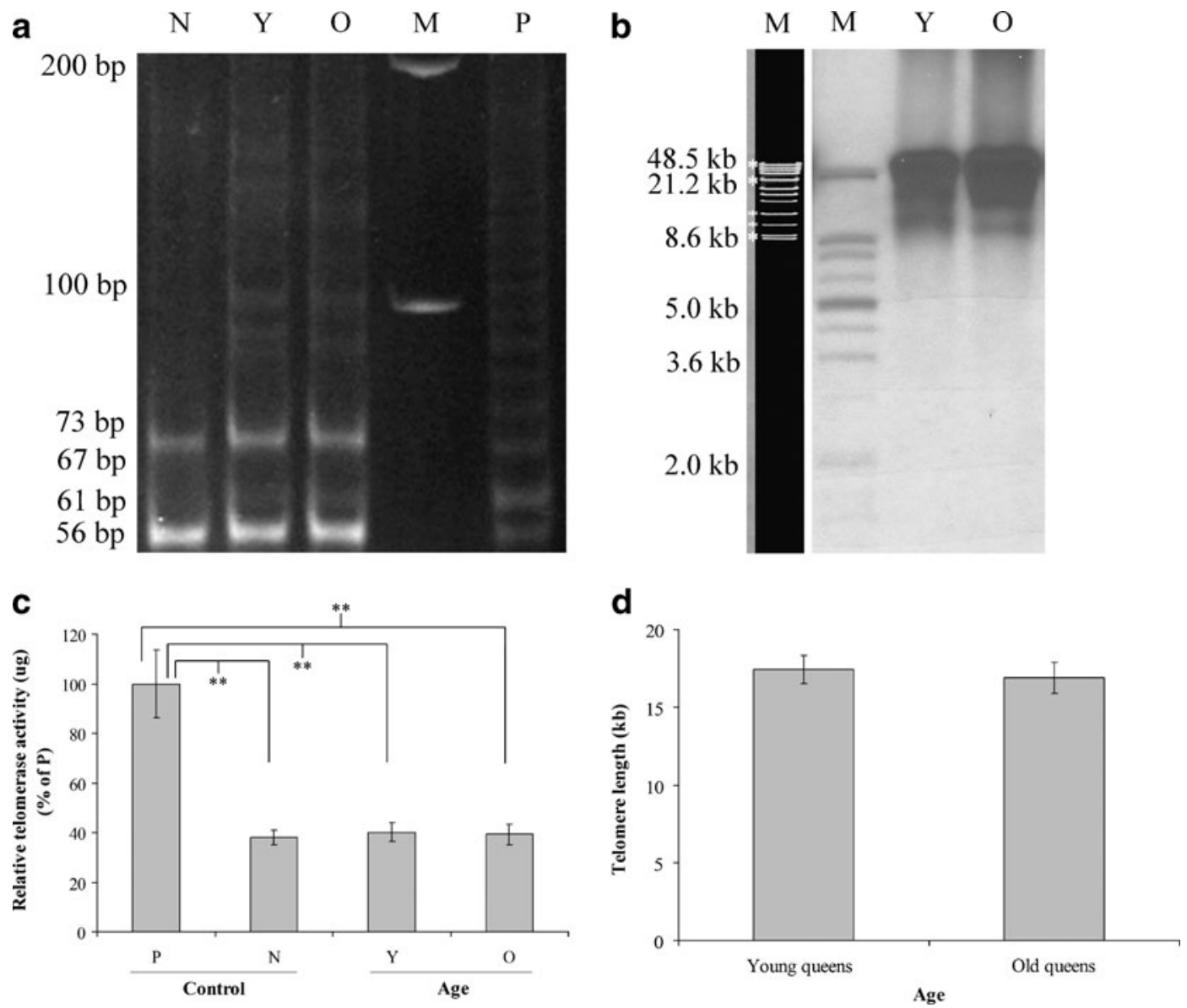

Figure 3. Telomerase activity and telomere length in the trophocytes and fat cells of young and old queens. a Telomerase activity. $P$ : positive control (293 T cells); $N$ : negative control; $Y$ : young queens; $O$ : old queens; $M$ : marker. b Telomere lengths. $M$ : marker; $Y$ : young queens; $O$ : old queens; asterisks: bands from the manufacturer's marker. c Quantification of telomerase activity in a. Bars represent mean \pm SEM $(N=3$ for each group). Asterisks indicate statistical significance as determined by one-way ANOVA $(* * P<0.01)$. d Quantification of telomere length in $\mathbf{b}$. Bars represent mean \pm SEM ( $N=3$ for each group).

the amino acid carbonyl contents using DNPH. The mean carbonyl-group levels in trophocytes and fat cells were $2.19 \pm 0.20 \mathrm{nmol} / \mathrm{mg}$ protein in young queens and $7.04 \pm 0.28 \mathrm{nmol} / \mathrm{mg}$ protein in old queens $(P<0.01)$, indicating that protein oxidation is associated with aging (Figure $5 b$ ).

\section{DISCUSSION}

In this study, we compared the cellular morphology and expression levels of agerelated molecules in the trophocytes and fat cells of young and old queen honeybees. Telomerase activity and telomere lengths showed no obvious differences with age, indicating that the trophocytes and fat cells do not divide in adulthood. Assays that measured agerelated molecules showed that the cells of old queens had increased SA- $\beta$-Gal expression, lipofuscin granules accumulation, lipid peroxidation, and protein oxidation compared to young queens. These results indicate that agerelated molecules can be used to evaluate aging in the trophocytes and fat cells of queens. 
a

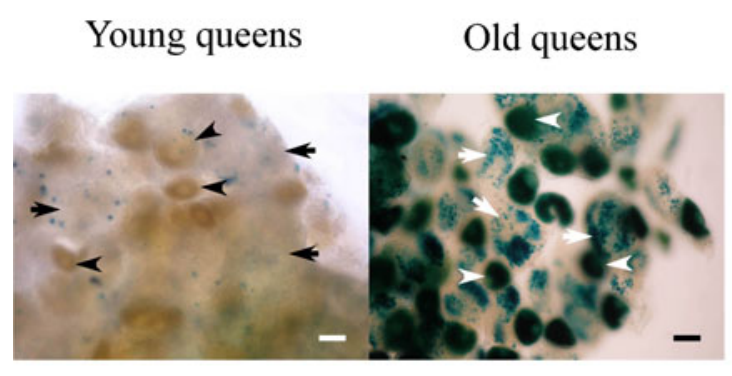

C

\section{Young queens $\quad$ Old queens}

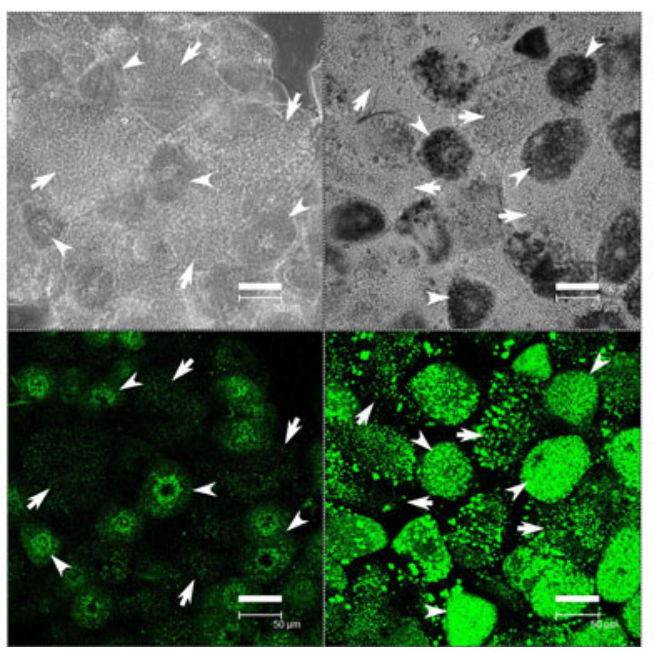

b

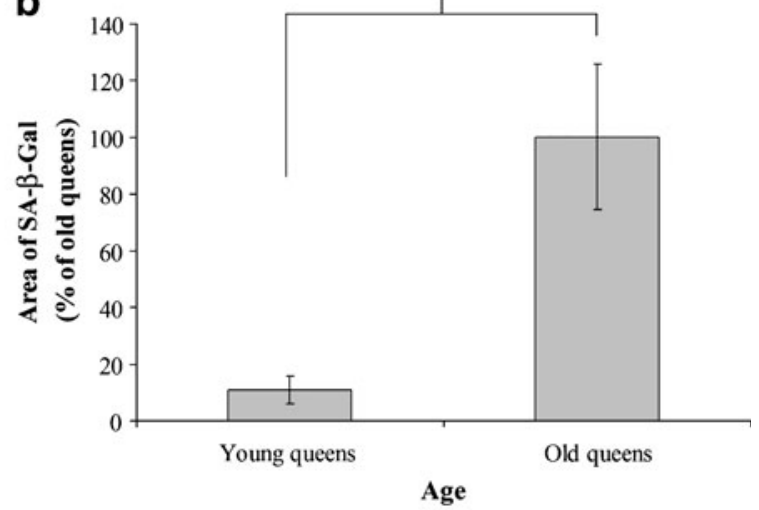

d

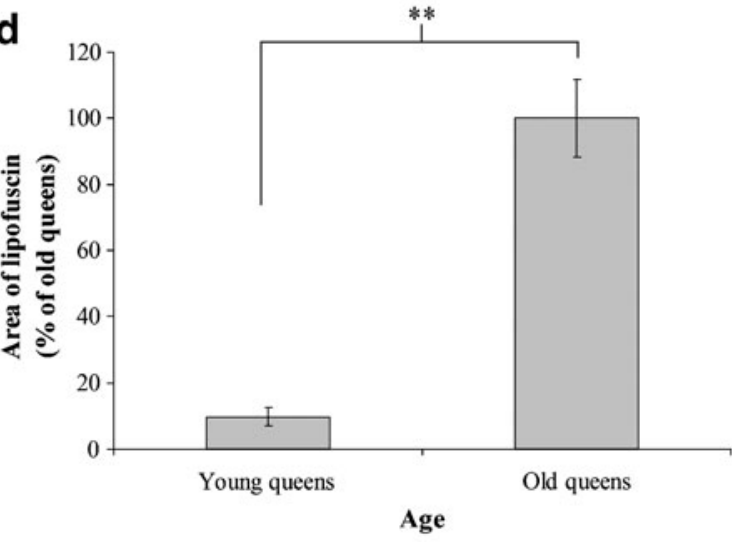

Figure 4. SA- $\beta$-Gal activity and lipofuscin granule accumulation in the trophocytes and fat cells of young and old queens. a Cellular SA- $\beta$-Gal activity was monitored by an enzymatic assay that employed X-gal as the substrate. Higher SA- $\beta$-Gal expression is associated with a more intense blue stain. Arrows point to trophocytes. Arrowheads point to fat cells. Scale bar, $25 \mu \mathrm{m}$. b Quantification of area that stained positive for SA- $\beta$-Gal activity. Bars represent mean \pm SEM ( $N=3$ for each group). Asterisks indicate statistical significance as determined by the two-sample $t$-test $(* P<0.05)$. c Bright-green-colored dots indicate lipofuscin granules. Micrographs were captured using fluorescence (lower panel) and bright field microscopy (upper panel). Arrows point to trophocytes. Arrowheads point to fat cells. Scale bar, $50 \mu \mathrm{m}$. d Quantification of area that contained lipofuscin granules. Bars represent mean \pm SEM ( $N=3$ for each group). Asterisks indicate statistical significance as determined by the two-sample $t$-test $(* * P<0.01)$.

\subsection{The cellular morphology of trophocytes and fat cells}

We previously assayed the cellular morphology of trophocytes in young and old workers (Hsieh and Hsu 2011). The cellular morphology showed remarkable differences between young and old workers. These differences are due to the accumulation of damaged or dysfunctional biological molecules and organelles (Hsieh and Hsu 2011). In this study, the cellular morphology of trophocytes and fat cells in young and old queens also showed obvious differences. These differences in cellular morphology and inclusion between young and old queens may result from age-related accumulation of damaged or dysfunctional biological molecules and organelles. 

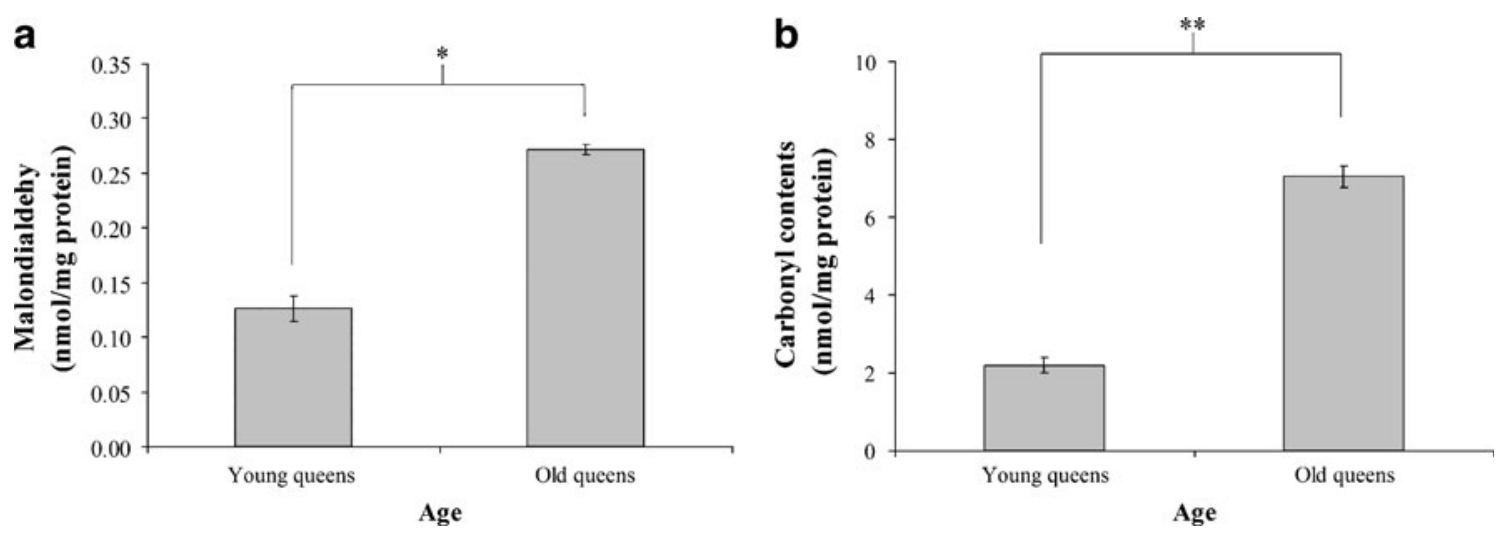

Figure 5. Lipid peroxidation (a) and protein oxidation (b) in the trophocytes and fat cells of young and old queens. Bars represent mean \pm SEM ( $N=3$ for each group). Asterisks indicate statistical significance as determined by the two-sample $t$-test $\left(* P<0.05,{ }^{* *} P<0.01\right)$.

\subsection{Telomerase activity and telomere length}

Previous studies have shown that telomerase activity decreases with increased age in sheep fibroblasts (Davis et al. 2005) and in human germline and embryonic tissues (Wright et al. 1996). Furthermore, the absence of telomerase activity results in telomeric shortening in dogs (Nasir et al. 2001), donkeys (Equus asinus), and horses (Equus equus) (Argyle et al. 2003). However, telomerase activity exhibits no apparent relationship with age in the muscles of zebrafish (Danio rerio) (Kishi et al. 2003) or $N$. rachovii (Hsu et al. 2008). Among insects, including silkworms (Bombyx mori) (Sasaki and Fujiwara 2000), flour beetles (Tribolium castaneum) (Osanai et al. 2006), and worker bees (Hsieh and Hsu 2011), telomerase activity does not appear to be age-dependent. Similarly, this study found no difference in telomerase activity with advancing age in the trophocytes and fat cells of queens.

Insect telomeres consist of a simple repetitive DNA sequence, (TTAGG)n, which differs from that of mammals, (TTAGGG)n (Okazaki et al. 1993; Sahara et al. 1999; Lorite et al. 2002; Osanai et al. 2006; Moyzis et al. 1988). Telomere shortening results in cellular senescence in rat cardiac tissue (Hastings et al. 2004), dog tissues (Nasir et al. 2001), sheep fibroblasts
(Davis et al. 2005), donkey and horse cells (Argyle et al. 2003), human cells (Lindsey et al. 1991), and muscles from N. rachovii (Hsu et al. 2008). Telomere lengths did not shorten with age in the trophocytes and fat cells of worker bees (Hsieh and Hsu 2011). Similarly, in this study, telomere lengths did not shorten with age in the trophocytes and fat cells of queens. Female ants (Lasius niger) also found that telomere length did not shorten (Jemielity et al. 2007).

The results of telomerase activity and telomere lengths indicate that trophocytes and fat cells in queens do not divide during adulthood. This finding corresponds to previous studies showing that trophocytes and fat cells in workers do not divide in adulthood (Hsieh and Hsu 2011; Ward et al. 2008). Therefore, the trophocytes and fat cells of honeybees are suitable for studying aging

\subsection{SA- $\beta$-Gal and lipofuscin granules}

SA- $\beta$-Gal expression increases with age. It has been used as a marker to assess cellular senescence in dermal fibroblasts and epidermal keratinocytes (Dimri et al. 1995), endothelial and smooth muscle cells from human and rabbit blood vessels (van der Loo et al. 1998; Kurz et al. 2000), the skin and dermis of zebrafish (Danio rerio) (Kishi et al. 2003), the skin and 
dermis of the annual fish Nothobranchius furzeri (Genade et al. 2005), the gills of the annual fish Nothobranchius rachovii (Hsu et al. 2008), and the trophocytes and fat cells of worker bees (Hsieh and Hsu 2011). In this study, the expression levels of SA- $\beta$-Gal in trophocytes and fat cells increased with the age of the queens, suggesting that cellular senescence increases with age. This result is consistent with previous studies (Dimri et al. 1995; van der Loo et al. 1998; Kurz et al. 2000; Kishi et al. 2003; Genade et al. 2005; Hsu et al. 2008) and is similar to the findings in worker bees (Hsieh and Hsu 2011).

Lipofuscin accumulates with age, and has been used as a marker in the evaluation of cellular senescence in the skin, dermis, and muscle of zebrafish (Danio rerio) (Kishi et al. 2003), brain and heart of rats (Nakano et al. 1995), neonatal cardiac myocytes of rats (Brunk and Terman 2002), liver and caudal peduncle of $N$. furzeri (Genade et al. 2005), gills of $N$. rachovii (Hsu et al. 2008), and the trophocytes and fat cells of worker bees (Hsieh and Hsu 2011). In this study, we found that the accumulation of lipofuscin in trophocytes and fat cells increased with the age of queens, indicating that cellular senescence increases with age. This result is consistent with previous studies (Kishi et al. 2003; Nakano et al. 1995; Brunk and Terman 2002; Genade et al. 2005; Hsu et al. 2008), and is similar to the findings in worker bees (Hsieh and Hsu 2011).

\subsection{Lipid peroxidation and protein oxidation}

Lipid peroxidation increases with age, and has been used as a marker in the assessment of cellular senescence in the adrenal glands of rats (Almeida et al. 1998), muscles of $N$. rachovii (Hsu et al. 2008), and the trophocytes and fat cells of worker bees (Hsieh and Hsu 2011). In this study, we found that lipid peroxidation increases with the age of queens, suggesting that cellular senescence increases with age. This result is consistent with previous studies (Almeida et al. 1998; Hsu et al. 2008) and similar to the finding in worker bees (Hsieh and Hsu 2011).

Protein oxidation increases with age, and has been used as a marker in the examination of cellular senescence in the muscle of Drosophila melanogaster (Sohal et al. 1993; Das et al. 2001), brain and liver of rats (Tian et al. 1998), lens cells from humans (Welis-Knecht et al. 1993), muscles of $N$. rachovii (Hsu et al. 2008), and trophocytes and fat cells of worker bees (Hsieh and Hsu 2011). In this study, we found that protein oxidation increases with the age of queens, revealing that cellular senescence increases with age. This finding is consistent with previous studies (Sohal et al. 1993; Das et al. 2001; Tian et al. 1998; Welis-Knecht et al. 1993; Hsu et al. 2008), and is similar to finding in worker bees (Hsieh and Hsu 2011). Protein carbonylation can result from ROS, oxidative cleavage of proteins, and lipid-derived aldehydes (Draper et al. 1986). It is more commonly caused by lipid-derived aldehydes than amino acid side chain oxidation (Yuan et al. 2007).

Increased SA- $\beta$-Gal expression, lipofuscin granule accumulation, lipid peroxidation, and protein oxidation may reflect an age-related decline in the efficiency of degradation and repair processes (Terman and Brunk 1998a, b; Ozawa 1997; Richter 1995) and a gradual accumulation of tissue damage (Sitte et al. 2000a, b).

\section{ACKNOWLEDGMENTS}

This work was supported by CMRPD 190631 grant from Chang Gung Memorial Hospital, Taiwan.

Modifications des molécules liées à l'âge dans les trophocytes et les cellules adipeuses des reines d'abeilles (Apis mellifera)

Vieillissement / trophocyte / cellule adipeuse / reine / abeille

Altersabhängige molekulare Veränderungen im Fettkörper von Königinnen der Honigbiene (Apis mellifera)

Alterung / Trophozyten / Fettzelle / Königin / Honigbiene 


\section{REFERENCES}

Almeida, H., Magalhães, M.C., Magalhães, M.M. (1998) Age-related changes in lipid peroxidation products in rat adrenal gland. Age 21, 119-121

Amdam, G.V., Page, R.E. (2005) Intergenerational transfers may have decoupled physiological and chronological age in a eusocial insect. Ageing Res. Rev. 4, 398-408

Amdam, G.V., Simões, Z.L.P., Hagen, A., Norberg, K., Schrøder, K., Mikkelsen, Ø., Kirkwood, T.B.L., Omholt, S.W. (2004) Hormonal control of the yolk precursor vitellogenin regulates immune function and longevity in honeybees. Exp. Gerontol. 39, 767-773

Argyle, D., Ellsmore, V., Gault, E.A., Munro, A.F., Nasir, L. (2003) Equine telomeres and telomerase in cellular immortalisation and ageing. Mech. Ageing Dev. 124, 759-764

Brunk, U.T., Terman, A. (2002) Lipofuscin: Mechanisms of age-related accumulation and influence on cell functions. Free Radic. Biol. Med. 33, 611-619

Camazine, S. (1991) Self-organizing pattern formation on the combs of honey bee colonies. Behav. Ecol. Sociobiol. 28, 61-76

Collins, A.M., Williams, V., Evans, J.D. (2004) Sperm storage and antioxidative enzyme expression in the honey bee, Apis mellifera. Insect Mol. Biol. 13, 141-146

Corona, M., Velarde, R.A., Remolina, S., Moran-Lauter, A., Wang, Y., Hughes, K.A., Robinson, G.E. (2007) Vitellogenin, juvenile hormone, insulin signaling, and queen honey bee longevity. Proc. Natl. Acad. Sci. USA 104, 7128-7133

Das, N., Levine, R.L., Orr, W.C., Sohal, R.S. (2001) Selectivity of protein oxidative damage during aging in Drosophila melanogaster. Biochem. J. 360, 209216

Davis, T., Skinner, J.W., Faragher, R.G., Jones, C.J., Kipling, D. (2005) Replicative senescence in sheep fibroblasts is a p53 dependent process. Exp. Gerontol. 40, 17-26

Dimri, G.P., Lee, X., Basile, G., Acosta, M., Scott, G., Roskelley, C., Medrano, E.E., Linskens, M., Rubelj, I., Pereira-Smith, O., Peacocke, M., Campisi, J. (1995) A biomarker that identifies senescent human cells in culture and in aging skin in vivo. Proc. Natl. Acad. Sci. USA 92, 9363-9367

Draper, H.H., Hadley, M. (1990) Malondialdehyde determination as index of lipid peroxidation. Methods Enzymol. 86, 421-431

Draper, H.H., McGirr, L.G., Hadley, M. (1986) The metabolism of malondialdehyde. Lipids 21, 305-307

Genade, T., Benedetti, M., Terzibasi, E., Roncaglia, P., Valenzano, D.R., Cattaneo, A., Cellerino, A. (2005) Annual fishes of the genus Nothobranchius as a model system for aging research. Aging Cell 4, 223-233
Hastings, R., Li, N.C., Lacy, P.S., Patel, H., Herbert, K. E., Stanley, A.G., Williams, B. (2004) Rapid telomere attrition in cardiac tissue of the ageing Wistar rat. Exp. Gerontol. 39, 855-857

Hsieh, Y.S., Hsu, C.Y. (2011) Honeybee trophocytes and fat cells as target cells for cellular senescence studies. Exp. Gerontol. 46, 233-240

Hsu, C.Y. (2004) The processes of iron deposition in the common hornet (Vespa affinis). Biol. Cell 96, 529-537

Hsu, C.Y., Chiu, Y.C. (2009) Ambient temperature influences aging in an annul fish (Nothobranchius rachovii). Aging Cell 8, 726-737

Hsu, C.Y., Li, C.W. (1993) The ultrastructure and formation of iron granules in the honeybee (Apis mellifera). J. Exp. Biol. 180, 1-13

Hsu, C.Y., Chiu, Y.C., Hsu, W.L., Chan, Y.P. (2008) Agerelated markers assayed at different developmental stages of the annual fish Nothobranchius rachovii. J. Gerontol. A Biol. Sci. Med. Sci. 63A, 1267-1276

Inal, M.E., Kanbak, G., Sunal, E. (2001) Antioxidant enzyme activities and malondialdehyde levels related to aging. Clin. Chim. Acta 305, 75-80

Jemielity, S., Keller, L. (2007) Aging: a young mind in old bees. Curr. Biol. 17, R294-R295

Jemielity, S., Kimura, M., Parker, K.M., Parker, J.D., Cao, X., Aviv, A., Keller, L. (2007) Short telomeres in short-lived males: what are the molecular and evolutionary causes? Aging Cell 6, 225-233

Kim, N.W., Wu, F. (1997) Advances in quantification and characterization of telomerase activity by the telomeric repeat amplification protocol (TRAP). Nucleic Acids Res. 25, 2595-2597

Kishi, S., Uchiyama, J., Baughman, A., Goto, T., Lin, M., Tsai, S. (2003) The zebrafish as a vertebrate model of functional aging and very gradual senescence. Exp. Gerontol. 38, 777-786

Kurz, D.J., Decary, S., Hong, Y., Erusalimsky, J.D. (2000) Senescence-associated $\beta$-galactosidase reflects an increase in lysosomal mass during replicative ageing of human endothelial cells. J. Cell Sci. 113, 3613-3622

Lindsey, J., McGill, N.I., Lindsey, L.A., Green, D.K., Cooke, H.J. (1991) In vivo loss of telomeric repeats with age in humans. Mutat. Res. 256, 45-48

Lorite, P., Carrillo, J.A., Palomeque, T. (2002) Conservation of (TTAGG) $n$ Telomeric sequences among ants (Hymenoptera, Formicidae). J. Hered. 93, 282285

Mecocci, P., Fano, G., Fulle, S., MacGarvey, U., Shinobu, L., Polidori, M.C., Cherubini, A., Vecchirt, J., Senin, U., Beal, M.F. (1999) Age-dependent increase in oxidative damage to DNA, lipids, and proteins in human skeletal muscle. Free Radic. Biol. Med. 26, 303-308

Moyzis, R.K., Buckingham, J.M., Cram, L.S., Dani, M., Deaven, L.L., Jones, M.D., Meyne, J., Ratliff, R.L., Wu, J.R. (1988) A highly conserved repetitive DNA sequence, (TTAGGG)n, present at the telomeres of 
human chromosomes. Proc. Natl. Acad. Sci. USA 85, 6622-6626

Nakano, M., Oenzil, F., Mizuno, T., Gotoh, S. (1995) Age-related changes in the lipofuscin accumulation of brain and heart. Gerontology 41, 69-79

Nasir, L., Devlin, P., McKevitt, T., Rutteman, G., Argyle, D.J. (2001) Telomere lengths and telomerase activity in dog tissues: a potential model system to study human telomere and telomerase biology. Neoplasia 3, 351-359

Neukirch, A. (1982) Dependence of the lifespan of the honeybee (Apis mellifera) upon flight performance and energy consumption. J. Comp. Physiol. 146, $35-40$

Okazaki, S., Tsuchida, K., Maekawa, H., Ishikawa, H. (1993) Identification of a pentanucleotide telomeric sequence, (TTAGG)n, in the silkworm Bombyx mori and in other insects. Mol. Cell. Biol. 13, 1424-1432

Oliver, C.N., Ahn, B.W., Moerman, E.J., Goldstein, S., Stadtman, E.R. (1987) Age-related changes in oxidized proteins. J. Biol. Chem. 262, 5488-5491

Omholt, S.W., Amdam, G.V. (2004) Epigenic regulation of aging in honeybee workers. Aging Knowl. Environ. 26, pe28

Osanai, M., Kojima, K.K., Futahashi, R., Yaguchi, S., Fujiwara, H. (2006) Identification and characterization of the telomerase reverse transcriptase of Bombyx mori (silkworm) and Tribolium castaneum (flour beetle). Gene 376, 281-289

Ozawa, T. (1997) Genetic and functional changes in mitochondria associated with aging. Physiol. Rev. $77,425-464$

Page, R.E., Peng, C.Y.S. (2001) Aging and development in social insects with emphasis on the honey bee, Apis mellifera L. Exp. Gerontol. 36, 695-711

Remolina, S.C., Hughes, K.A. (2008) Evolution and mechanisms of long life and high fertility in queen honey bees. Age 30, 177-185

Remolina, S.C., Hafez, D.M., Robinson, G.E., Hughes, K.A. (2007) Senescence in the worker honey bee Apis mellifera. J. Insect Physiol. 53, 1027-1033

Richter, C. (1995) Oxidative damage to mitochondrial DNA and its relationship to ageing. Int. J. Biochem. Cell Biol. 27, 647-653

Robertson, H.M., Gordon, K.H.J. (2006) Canonical TTAGG-repeat telomeres and telomerase in the honey bee, Apis mellifera. Genome Res. 16, 1345-1351

Rueppell, O., Christine, S., Mulcrone, C., Groves, L. (2007a) Aging without functional senescence in honey bee workers. Curr. Biol. 17, R274-R275

Rueppell, O., Bachelier, C., Fondrk, M.K., Page Jr., R.E. (2007b) Regulation of life history determines lifespan of worker honey bees (Apis mellifera L.). Exp. Gerontol. 42, 1020-1032

Sahara, K., Marec, F., Traut, W. (1999) TTAGG telomeric repeats in chromosomes of some insects and other arthropods. Chromosome Res. 7, 449-460
Sasaki, T., Fujiwara, H. (2000) Detection and distribution patterns of telomerase activity in insects. Eur. J. Biochem. 267, 3025-3031

Seehuus, S.C., Krekling, T., Amdam, G.V. (2006a) Cellular senescence in honey bee brain is largely independent of chronological age. Exp. Gerontol. 41, 1117-1125

Seehuus, S.C., Norberg, K., Gimsa, U., Krekling, T., Amdam, G.V. (2006b) Reproductive protein protects functionally sterile honey bee workers from oxidative stress. Proc. Natl. Acad. Sci. USA 103, 962 967

Sitte, N., Merker, M., von Zglinicki, T., Davies, K.J.A., Grune, T. (2000a) Protein oxidation and degradation during cellular senescence of human BJ fibroblasts: part I-effects of proliferative senescence. FASEB J. 14, 2495-2502

Sitte, N., Merker, M., von Zglinicki, T., Davies, K.J.A., Grune, T. (2000b) Protein oxidation and degradation during cellular senescence of human BJ fibroblasts: part II-aging of nondividing cells. FASEB J. 14, 2503-2510

Sohal, R.S., Agarwal, S., Dubey, A., Orr, W.C. (1993) Protein oxidative damage is associated with life expectancy of houseflies. Proc. Natl. Acad. Sci. USA 90, 7255-7259

Terman, A., Brunk, U.T. (1998a) On the degradability and exocytosis of ceroid/lipofuscin in cultured rat cardiac myocytes. Mech. Ageing Dev. 100, 145-156

Terman, A., Brunk, U.T. (1998b) Ceroid/lipofuscin formation in cultured human fibroblasts: The role of oxidative stress and lysosomal proteolysis. Mech. Ageing Dev. 104, 277-291

Tian, L., Cai, Q., Wei, H. (1998) Alterations of antioxidant enzymes and oxidative damage to macromolecules in different organs of rats during aging. Free Radic. Biol. Med. 24, 1477-1484

Tofilski, A. (2000) Senescence and learning in honeybee (Apis mellifera) workers. Acta Neurobiol. Exp. 60, 35-39

van der Loo, B., Fenton, M.J., Erusalimsky, J.D. (1998) Cytochemical detection of a senescence-associated b-galactosidase in endothelial and smooth muscle cells from human and rabbit blood vessels. Exp. Cell Res. 241, 309-315

Ward, K.N., Coleman, J.L., Clinnin, K., Fahrbach, S., Rueppell, O. (2008) Age, caste, and behavior determine the replicative activity of intestinal stem cells in honeybees (Apis mellifera L.). Exp. Gerontol. 43, 530-537

Weirich, G.F., Collins, A.M., Williams, V.P. (2002) Antioxidant enzymes in the honey bee, Apis mellifera. Apidologie 33, 3-14

Welis-Knecht, M.C., Huggins, T.G., Dyer, G., Thorpe, S.R., Baynes, J.W. (1993) Oxidized amino acids in lens protein with age. J. Biol. Chem. 268, 12348-12352

Williams, J.B., Roberts, S.P., Elekonich, M.M. (2008) Age and natural metabolically-intensive behavior 
affect oxidative stress and antioxidant mechanisms. Exp. Gerontol. 43, 538-549

Winston, M.L. (1987) The biology of the honey bee. Harvard University Press, Cambridge, MA

Wright, W.E., Piatysek, M.A., Rainey, W.E., Byrd, W., Shay, J.W. (1996) Telomerase activity in human germline and embryonic tissues and cells. Dev. Genet. 18, 173-179
Yuan, Q., Zhu, X., Sayre, L.M. (2007) Chemical nature of stochastic generation of protein-based carbonyls: metal-catalyzed oxidation versus modification by products of lipid oxidation. Chem. Res. Toxicol. 20, 129-139

Zheng, J., Mutcherson, R., Helfand, S.L. (2005) Calorie restriction delays lipid oxidative damage in Drosophila melanogaster. Aging Cell 4, 209-216 